67 巻 655 号 $(2001-3)$

\title{
同軸二重円筒間の自然対流場の準定常性とカオス性*
}

\author{
石田秀士*1, 五味 学*2, 木本 日出夫*1
}

\section{Quasi-static and Chaotic Characteristics of the Natural Convection Field Between Concentric Vertical Annuli}

\author{
Hideshi ISHIDA*3, Manabu GOMI and Hideo KIMOTO \\ *3 Osaka University, Graduate School of Engineering Science, \\ 1-3 Machikaneyama-cho, Toyonaka, Osaka, 560-8531 Japan
}

\begin{abstract}
In this study unsteady and chaotic characteristics of the thermal convection fields between concentric annuli were experimentally examined, and they were compared with the previously reported fields in a vertical slot. The inner cylinder was heated by a embedded heater and the outer one was cooled by temperature-controlled cold water, and the $84 \mathrm{wt} \%$ glycerol-water solution was used for the present test fluid. The main results are as follows: (1) The region where the characteristic frequency of temperature-variation is detected is located at the upper portion of the region where the secondary cells exist. (2) The time scale of the temperature change at which autocorrelation function becomes $1 / \mathrm{e}$ is relatively small in the secondary-cell region, and this corresponds to the result of the natural convection field in a vertical slot. (3) The significant chaotic characteristics in the temperature-variation are determined in almost the same region where the characteristic frequency of temperature-variation is detected, which is peculiar to the field of the present study.
\end{abstract}

Key Words : Natural Convection, Experimental Analysis, Vertical Annulus, Quasi-Steady, Chaotic Characteristics, Secondary Cells

\section{1. 緒言}

密閉された鉛直同軸二重円筒間内部の自然対流場は 圧力容器や，原子炬とその外部シールド間の熱対流場 等の物理モデルとしてこれまで数多くの研究が行われ ている。これらの多くは実用的見地から熱伝達面での 壁表面平均ヌセルト数を重点的に报っており ${ }^{122)}$ ，系内 の熱对流場を报ったものは比較的少ない。

Fujii ら ${ }^{3)}$ は内円筒において発熱量一定とした場合に ついて，可視化により伝熱面近傍の流れ場を 4 通りに 分類した上で局所グラスホフ数（同所レイレー数）の 変化に伴う時間平均局所ヌセルト数の変化や時間平均 温度場について詳細に検討している.また熱対流場の 定性的傾向についてはブシネスク近似を用いて数多く の数値計算が行われており，半径比（二外円筒半径/内円 筒半径)やアスペクト比が変化した場合の流れ場の変

* 原稿受付 2000 年 7 月 13 日.

*1 正貣, 大阪大学大学院基礎工学研究科（沓 560-8531 豊中市 待兼山町 1-3).

*2 大阪大学大学院.

E-mail : ishidå@me.es.osaka u. ac.jp
化が論じられている゙ほか，検査流体に水を用いた場合， 最大密度線を境にして内円筒，外円筒側にそれぞれ逆 回転の洞領域が発生じ，それぞれが鈶直方向に 2 次流 れセルを伴って振動することが知られている。.しかし ながら同軸二重円筒間の熱対流場の非定常特性につい ては定性的傾向はともかく定量的に扱っているものは 見あたらない.またプラントル数による影響や物性値 の温度変化が非定常特性に与える影響について検討し ているものも皆無である.

一方非定常特性の一つとして近年熱対流場のカオス 性について数多くの報告がある．この力オス性の存在 は現象のヒステリシス や不安定性 ${ }^{8)}$ と関係があり，ま たこのカオス性や非定常特性から求まる幾何学特性は 現象の分類や流れのモード変化を分析する上で非常に 有効であることが明らかとなっているか9.

静止した密閉容器槽内部のカオス性を报った例とし て，著者ら ${ }^{100}$ は鈶值平行平板間の自然対流場において 作業流体に高プラントル数のグリセリン水溶液を用い た場合について実験的に調べ，グラスホフ数を大きく した場合に発生する2 次流れセルの空間的な存在領域 が温度場の非定常状態が観察される領域にほぼ対応し， 
またその領域の内部に温度場のカオス的変動が見られ る領域が存在することを明らかにした。また温度場の 時間変動スケールは高さ方向に減少し，カオス性につ いても比較的槽内下部でピークが観察されるとそのあ とは高さ方向に減少することが明らかとなった。この 鈶直平行平板間の流れ場は同軸二重円筒間の流れ場に ついて半径比を 0 の極限にとつた場合に相当しており, 上記の性質が内円筒半径が有限の同軸二重円筒間内や 別の温度境界条件下でどのように変化するかは興味深 いところである.

そこで本研究においては作業流体に高プラントル数 溶液であるグリセリン水溶液を用い，内円筒を一定発 熱のヒーターで加熱した場合に，内外円筒間内に形成 される自然対流場の準定常性並びにカオス性について 定量的に調べ，鉛直平行平板間の自然対流場との比較 検討を行った.

\section{a : 熱拡散係数}

\section{2. 記 号}

$\mathrm{C}_{\mathrm{p}}$ : 定圧比熱

$\mathrm{f}:$ 無次元周波数

$\mathrm{g}:$ 重力加速度

$\mathrm{Gr}:$ グラスホフ数

$\mathrm{H}:$ 水溶液の高さ

$\mathrm{k}$ : 熱伝尊率

$K:$ 半径比 $\left(=R_{\circ} / R_{i}\right)$

$\mathrm{L}$ : 代表長さ $\left(=\mathrm{R}_{\mathrm{o}}-\mathrm{R}_{i}\right)$

$\mathrm{Pr}:$ プラントル数

$\mathrm{q}$ ：加熱量

$r:$ 無次元半径方向座標 $(=R / L)$

$\mathbf{R}$ : 半径, 半径方向座標

$\mathrm{Ra}$ : レイリ一数

$\mathrm{t}:$ 無次元時間

$\mathrm{T}:$ (無次元)温度

$\mathbf{V}:$ 速度

$z$ : 無次元鉿直方向座標 $(=\mathrm{Z} / \mathrm{L})$

$\mathrm{Z}:$ 鈶直方向座標

$\alpha:$ アスペクト比(=H/L)

$\beta:$ 体膨張保数

$\Delta \mathrm{T}:$ 無次元温度振幅

$\theta:$ 周方向角度

$\Theta:$ 代表温度差 $(=\mathrm{q} L / \mathbf{k})$

$\lambda$ : 最大リアプノフ指数

$\mu:$ 粘性係数

$v:$ 動粘性率

$\rho:$ 密度

$\tau:$ 自己相関係数から求まる時間スケール

源字

$\mathrm{i}$ : 内円筒, いずれかの温度測定点

$\max :$ 最大値

$\min :$ 最小値
$0:$ 外丹筒

$0 \sim 11:$ 温度測定点

\section{3 . 実験装置及び方法}

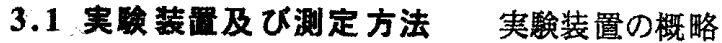

図と座標軸を図 1 に示す．本実験においては検查体積 （テストセクション）を值径 $34.1 \mathrm{~mm}$ のヒータが埋め 込まれた直径 $50.0 \mathrm{~mm}$ の真鍮製内円筒と厚さ $3.6 \mathrm{~mm}$ 内 径 $132.4 \mathrm{~mm}$ のガラス製外円筒からなる同軸二重円筒 間内にとる，それぞれの円筒はポリアセタール製の台 座の上に固定されているが，上端は大気開放にするこ とで上部から検查体積内部への操作を可能にしている. 本実験では内外円筒の直径は変化させないので半径比 $\mathrm{K}\left(=\right.$ 外丹筒内径 $\mathrm{R}_{\mathrm{o}} /$ 内円筒半径 $\left.\mathrm{R}_{\mathrm{f}}\right)$ は 2.65 一定である.

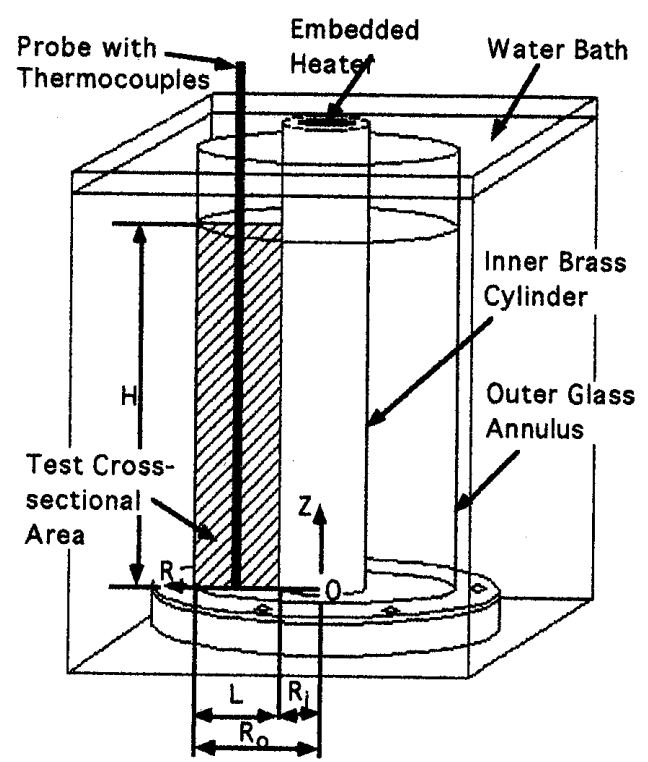

Fig. 1 Experimental setup and coordinate definition

外円筒はアクリル製椧却水槽内部に設置しているが, 実験中は泠却水を水槽之空冷式冷却装置との間で循䍗 させ，その水を水槽内に設置した温度調節用ヒ一ター により加熱することで水槽内温度 $\mathrm{T}_{0}$ を $10^{\circ} \mathrm{C}$ 一定(誤差 $\pm 0.2 \mathrm{C}$ )に保った。.また内円筒内部のヒーターに一定 電圧をかけることで内円筒の発熱量を一定に保ったが, その電圧はボルトスライダーを用いて調節した。作業 流体には 84wt\%ダリセリン水溶液を用い，水溶液の高 さ H=450mm を一定に保つことで図 1 の斜線で示され る半径方向の検查面のアスペクト比 $\alpha\left(=\mathrm{H} / \mathrm{L}, \mathrm{L}=\mathrm{R}_{\mathrm{o}}-\mathrm{R}_{\mathrm{i}}\right)$ を 10.9 一定に保った.

本実験では温度の測定のため 17 本の素線径 $0.1 \mathrm{~mm}$ の銅・コンスタンタン熱電対を取り付けた線状測温プ ルーブをテストセクション上部から円筒間中央 $\left(\mathrm{R}=\left(\mathrm{R}_{\mathrm{i}}+\mathrm{R}_{\mathrm{o}}\right) / 2\right)$ に㨂入し, $2 \leqq Z \leqq 450 \mathrm{~mm}$ の範囲の温度の 定点観測 $(100 \leqq Z \leqq 450 \mathrm{~mm}$ では $25 \mathrm{~mm}$ 間隔)を行った. 
その際それぞれの熱電対の起電力をデジタルマルチメ 一タで増幅し，その電圧值を GP-IB バスを介してパソ コンに 5 秒間隔で取り込み記録並びにデー夕処理を行 った. また㭘査流体にアルミ粉を混入させ，透明な冷 却水槽外部からハロゲンランプー光学スリット系を用 いてある R-Z 断面に照射することで自然対流場を可視 化し，それを同じく外部からデジタルカメラで一定時 間間隔で撮影した。

\section{2 実駼条件 本実験では参照温度を水槽内温} 度 $\mathrm{T}_{0}$ としてこれを $10^{\circ} \mathrm{C}$ 一定に保つことで作業流体の プラントル数 $\mathrm{Pr}=1.8 \times 10^{3}$ 一定に保ち, 内円筒の単位 面積当たりの加熱量 $\mathrm{q}$ を変化させることで次式で定義 される代表温度差 $\Theta$ に基づくグラスホフ数 $\mathrm{Gr}$

$$
G r=\frac{g \beta \Theta L^{3}}{v^{2}}, \Theta=q L / k
$$

を 6 通りに変化させた. 対応するレイリ一数 $\mathrm{Ra}(=\mathrm{Gr} \times$ Pr)はそれぞれ $\mathrm{Ra}=1.4,2.0,2.2,2.6,3.2$ そして $4.3 \times$ $10^{6}$ である。ここでグリセりン水溶液の物性值は Segur ${ }^{11)}$ にった.

実験に際しては加熱量 $\mathrm{q}=0$ で水槽内温度 $\mathrm{T}_{0}=10^{\circ} \mathrm{C}$ 定に保ち，このまま長時間放置することでテストセク ション内で一様に温度 $\mathrm{T}=10^{\circ} \mathrm{C}$, 速度 $\mathrm{V}=0$ を寒現し, これを初期条件とした. そして実験開始時にヒーター 加熱量を上記の所定の値にセット・維持し，約 22 時間 の連続実験を行った.

実験に先立つて周方向角度 $\theta=0,180^{\circ}$ の二つの R-Z 断面において同時に流机場を可視化し，さらに両断面 において同時に温度場を測定することであらかじめ熱 対流場の周方向一様性を確認している. また実験に使 用する熱電対に対しても誤差が士0.1 ${ }^{\circ} \mathrm{C}$ 以内に収まる よう較正した上で，それらの応答性についても問題の ないことを確認している8

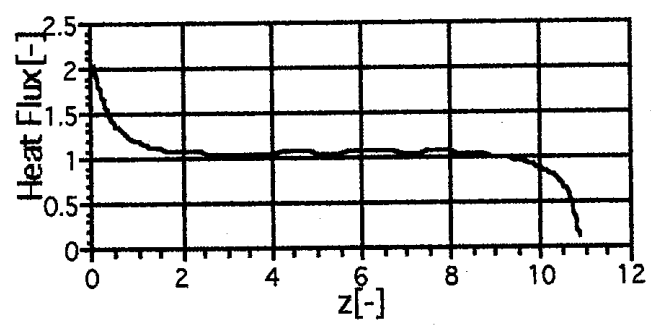

Fig.2 Estimated heat flux on the inner cylinder

また，ヒ一夕を真鍮内円筒にはめ込むことによる内 円筒表面での一定発熱条件からのズレを考察するため， 数值解析による予備検討を行った. 計算の際はブシネ スク近似を施した粘性の温度変化を考慮しない基礎式 に対して周方向の一様性を仮定して二次元化した上で それを有限差分法により 2 次精度で離散化して数值解
を得た. 数値解析結果については高さ方向の 2 次流れ セルの生成や高さ方向の温度レベルの一致等の実験結 果との対応を確認している.

$\mathrm{Ra}=3.2 \times 10^{6}$ のケースについて寒際の真鍮内表面で の熱流束と，ヒ一夕の総発熱量から換算される内表面 で熱流束一定とした場合の熱流束との比を図 2 に示し ている.この図に示すとおり熱流束は高さ方向にほぼ 一様で, 無次元高さ $\mathrm{z}(=\mathrm{Z} / \mathrm{L})$ について $0.5<z<10.5$ の範 囲では実際の熱流束が一定熱流束条件下での熱流束と 比較して誤差 30\%の範囲内におさまっており, 多くは 誤差 10\%以内である.このことから本実験結果はほぼ 内円筒表面で熱流束一定とした場合の実験結果とみな すことができる.

\section{4. 実験結果}

\section{1 熱対流場の定性的傾向 実験開始直後加} らの無次元温度の時間変化の例として $\mathrm{Ra}=3.2 \times 10^{6}$ の 場合について図3に示している. 以下で扱う無次元量 证基本的に赛次元の物理量を代表長さ $\mathrm{L}$, 熱拡散係数 $\mathrm{a}$, 代表温度差 $\Theta て ゙$ 無次元化したものであり，無次元温度 としては実次元温度から水槽温度 $\mathrm{T}_{0}$ を差し引いたもの をので割ったものを採用した。

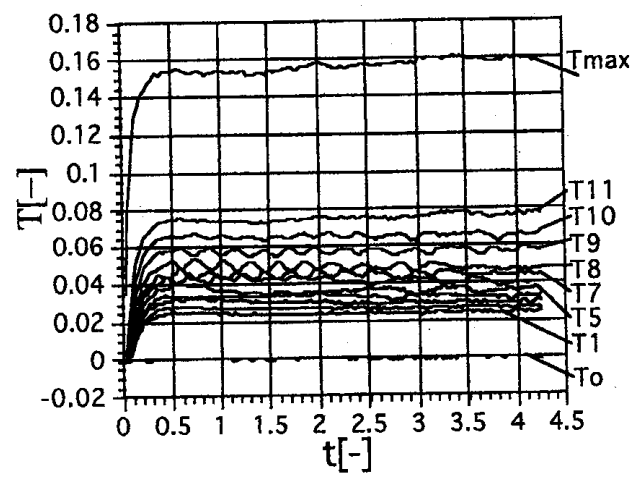

Fig. 3 Temperature-variation at measuring points

図中で $\mathrm{T}_{1}$ ～ $\mathrm{T}_{11}$ はそれぞれ $\mathrm{Z}=100 \mathrm{~mm}$ から $350 \mathrm{~mm}$ (無 次元座標 $\mathrm{z} て 2 ~ 2.43 \sim 8.50)$ まで $25 \mathrm{~mm}$ 間隔 11 点の各測 定点での無次元温度を示しており， $\mathrm{T}_{\text {max }}$ は $\mathrm{Z}=\mathrm{H}($ 作業流 体の自由表面上)での無次元温度を示している. 図で示 されているとおり，作業流体内部の測定点での温度は 無次元時間 $\mathrm{t}=1$ 以降でほぼ一定となり，測定点によっ ては時間平均值の周りで温度変動が見られる. 図 4 に この状態での可視化画像を示しているが，鈶直方向に 洞列 (2 次流机セル)が形成されており，それらが移動 $(\mathrm{t}=0.998,1.06)$, 生成 $(\mathrm{t}=1.13)$, 合体 $(\mathrm{t}=1.19)$ を繰り返し ているものの, 2 次流れセルの総数はほとんど変化し ていない.このような状態を既報 ${ }^{10)}$ と同様本研究では 準定常状態と定義した. 
Table 1 The range of $\mathrm{z}$ where the secondary cells exist

\begin{tabular}{ccccccc}
\hline Rax $10^{-6}$ & 1.4 & 2.0 & 2.2 & 2.6 & 3.2 & 4.3 \\
\hline Lower Limit[z] & - & 5.6 & 4.4 & 4.1 & 3.0 & 1.7 \\
Upper Limit[z] & - & 7.8 & 7.5 & 7.3 & 7.9 & 7.5 \\
Secondary Cell Number & 0 & 1 & $1-2$ & $2-3$ & $3-4$ & $3-4$ \\
\hline
\end{tabular}

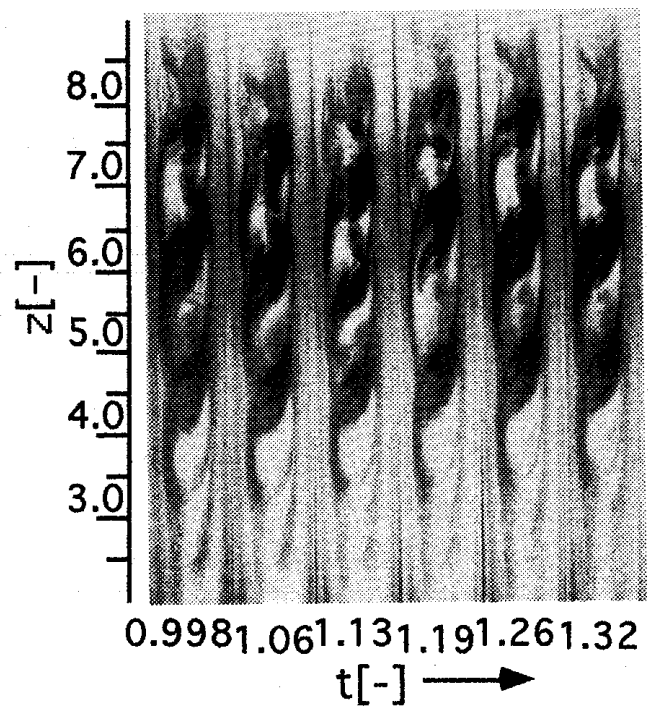

Fig.4 Visualized flow pattern with time $\left(\mathrm{Ra}=3.2 \times 10^{6}\right)$

本研究では準定常状態における可視化画像から鈶直 方向に 2 次流れセルの存在が認められる範围を調べた。 その結果を表 1 に示しているが，レイレ一数が大きく なるにつれて，2次流れセル発生範囲の上限がほぼ一 定なのに対し，下限が下方へ移動している. この結果 は側壁温度を固定した鈶值平行平板間の自然対流場 ${ }^{10}$ では中心から上下方向に 2 次セル発生範国が広がる傾 向を示すのとは大きく異なっているが，これは一定発 熱により高さ方向の温度変化（粘性変化）が大きいの と，またたとえ物性値，側壁温度共に一定であっても 同軸二重円筒間内の二次元熱対流場は中心対称とはな らないことの両方の影響であると考えられる.

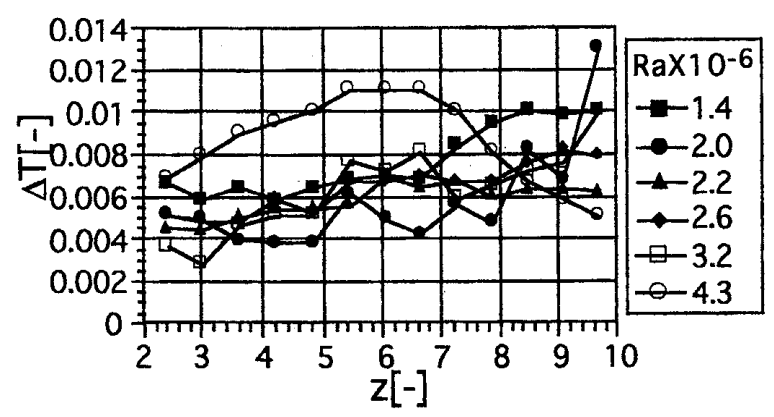

Fig. 5 Amplitude of temperature at the measuring points for various $\mathbf{R a}$

また準定常状熊における各測定点での温度 $\mathrm{T}_{\mathrm{i}}$ の時間 変動の最大值 $\mathrm{T}_{\mathrm{i} \max }$ 及び最小值 $\mathrm{T}_{\mathrm{i} \text { min }}$ から温度の無次元
Table 2 The measuring points where the characteristic frequency is detected

\begin{tabular}{ccccc}
\hline$z$ & \multicolumn{4}{c}{$\operatorname{Ra} \times 10^{-6}$} \\
\cline { 2 - 5 }$[-]$ & 2.2 & 2.6 & 3.2 & 4.3 \\
\hline 2.4 & - & - & - & \\
3.0 & - & - & - & 0 \\
3.6 & - & - & - & 0 \\
4.3 & - & - & - & 0 \\
4.9 & - & - & - & 0 \\
5.5 & 0 & 0 & - & 0 \\
6.1 & 0 & 0 & 0 & 0 \\
6.7 & 0 & 0 & 0 & 0 \\
7.3 & 0 & - & 0 & 0 \\
7.9 & - & - & 0 & 0 \\
8.5 & - & - & - & 0 \\
9.1 & - & - & - & 0 \\
9.7 & - & - & - & 0 \\
\hline
\end{tabular}

変動振幅 $\Delta T\left(=T_{i_{\text {max }}}-T_{i_{\min }}\right)$ を求めた. 結果を図 5 に示し ている.この図に示しているとおり, 温度変動振幅は 高さ方向に大きくなる傾向があり，2次流れセルの存 在する領域(表 1)之温度振幅が大きい領域との対応は

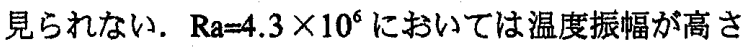
方向に最大值をとつたあと減少するという他のケース と異なった傾向が認められるが，これは鉛直平行平板 間で観察されるトラベリングウェーブ(2)を伴う流れへ の遷移の前兆現象であると考えられる. しかしながら 本研究においては $R a=3.2 \times 10^{6}$ の場合と比較して, 予 想される流れのモード変化を可視化画像上で確認する ことはできなかった。

4.2 周波数分析 次に温度場の自励振動の特徽 を定量的に把握するため注定常状態における温度デー 夕の周波数分析を行った. 代表的な例として $\mathrm{Ra}=4.3 \times$ $10^{6}, z=4.85$ における温度のパワースペクトルを図 6 に示している. この例では無次元周波数 $\mathrm{f}=6$ 付近でノ イズとは明らかに異なる比較的大きなパワースペクト ルが検出されているが，このような温度変動に特徵的 な周波数の存在が確認された測定点を表 2 に”○”で示 している. 表には示していないがこれらの特徽周波数 の多くは3〜6の間に分布している.

表 1 と表 2 を比較すると特徴周波数の存在する領域 は 2 次セル発生領域の上部にほぼ対応していることが 分かる.この結果は既報 ${ }^{10}$ において側壁温度を固定し た鉛直平行平板間の自然対流場では特徽的な周波数の 存在領域が 2 次セル発生領域にほぼ対応するという事 実と異なっており，本実験条件下で特有の性質である。

また表 1 ，表 2 によると $\mathrm{Ra}=4.3 \times 10^{6}$ のケースでは 2 次セル発生領域の上部にも特街周波数が存在する領 域が確認されている.このケースでは 2 次セル発生領 
域の上限近傍で特徽周波数が 3 から 0.5 まで減少し， z=8.5 9.7においてほぼ 0.5 一定である.これは前節 で述べた高さ方向の流れの構造の変化による影響と考 えられる。

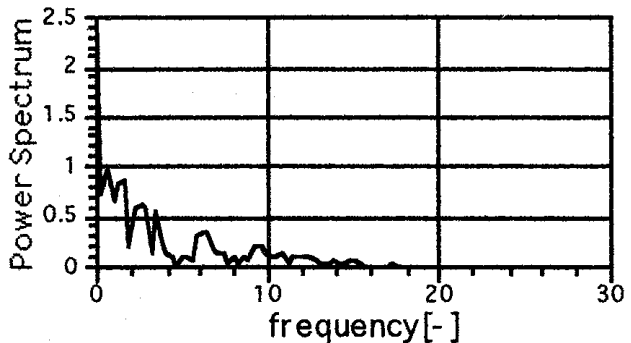

Fig. 6 Power Spectrum $\left(\mathrm{Ra}=4.3 \times 10^{6}\right.$ and $\left.\mathrm{z}=4.85\right)$

$4.3 \mathrm{ACF}$ による時間スケールの算出 次に温 度変動の時間スケールを捉える別の方法として, 既報 10) と同じ方法により準定常状態における温度の時系列 テータから自己相関係数 (ACF: Auto-Correlation Function)が $1 / \mathrm{e}$ になるスケールてを求めた. 後述の最 大リアプノフ指数の計算の際に問題となる温度変動の 高周波ノイズの影響を避けるため，計算にはあらかじ め測定データに対して既報 ${ }^{8)}$ で用いた一階微分方程式 に基づくローパスフィルタ ${ }^{13)}$ (遮断周波数 $\mathrm{f}=20$ )を施し た時系列データを用いた. 結果を図 7 に示している.

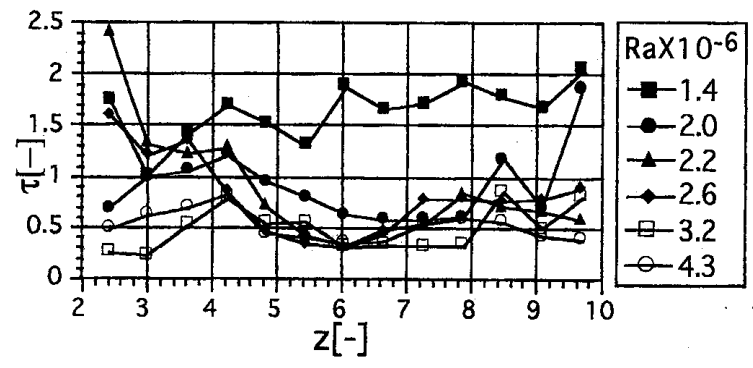

Fig. 7 The time scale $\tau$ at which auto-correlation function becomes $1 / \mathrm{e}$ for various $\mathrm{Ra}$

表 1 と図 7 を比較すると 2 次流れセルが存在する領 域では高さの増大に伴ってて は下に凸の変化をしてお り，極小值は前節の特徽周波数の逆数のオーダーにほ ぼ等しくなっている. その他の領域では $\tau$ は比較的大 きい.これは既報 ${ }^{10)}$ の鉛直平行平板間の自然対流場に おいて 2 次流机セルの存在する領域で $\tau$ が小さくなる 事実と対応している. また $\operatorname{Ra} \times 10^{-6}=2.0,3.2,4.3$ のケ 一スでは $\mathrm{z}=2$ 近傍で $\tau$ が小さくなっているが, この領 域ではもともと温度振偪が実次元で $0.3^{\circ} \mathrm{C}$ 程度で極め て小さくノイズによる影響が考えられる.

また $\mathrm{Ra}=4.3 \times 10^{6}$ のケースでは他のケースと異なり， 2 次セル発生領域の上部で $れ$ は比較的小さい值 $(\tau \leqq$ 0.6）に維持されている.

\section{4 最大リアプノフ指数 最後に準定常状熊} における温度の時系列デー夕から力学系の初期值に対 する鋭敏な依存性を判別する指標である最大りアプノ フ指数 $\lambda$ を求めた．計算手法としては Wolf ${ }^{14)} の$ 方法を 採用し，時系列デ一夕には前節と同じく準定常状態の 測定デー夕に対してローパスフィルタを施したものを 使用した.

既報 ${ }^{10)}$ と同様，最小探索スケールと最大探索スケー

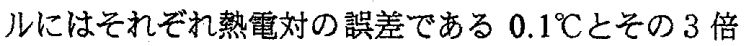
$\left(0.3^{\circ} \mathrm{C}\right)$ を用いた. このことによりてで問題となった温 度変動のノイズの影響を抑えることができる. 次に埋 め込み次元，遅れ時間，発展時間は既報 ${ }^{10)}$ と同様ある 最適値の周りで $\lambda$ がほぼ一定であること(stationarity) を確認し，それらの值の平均値とばらつきから入の確 定値とその誤差範囲(確率 $50 \%$ で変動する範囲)を計算 した．遅え時間を変化させる際は基本的に既報と同じ く ACFが 1/e になるスケール $\tau$ を基準とし，その値に 対する倍率をパラメータにとったが，て>0.5 のケース についてはその基準スケールとして $\tau=0.5$ に固定した。 このような基準時間スケールを用いることにより $\mathrm{Ra}=1.4 \times 10^{6}, 2.0 \times 10^{6}$ において埋め込夕次元を変化さ せた場合を除き， $\lambda の$ stationarity を確認した.

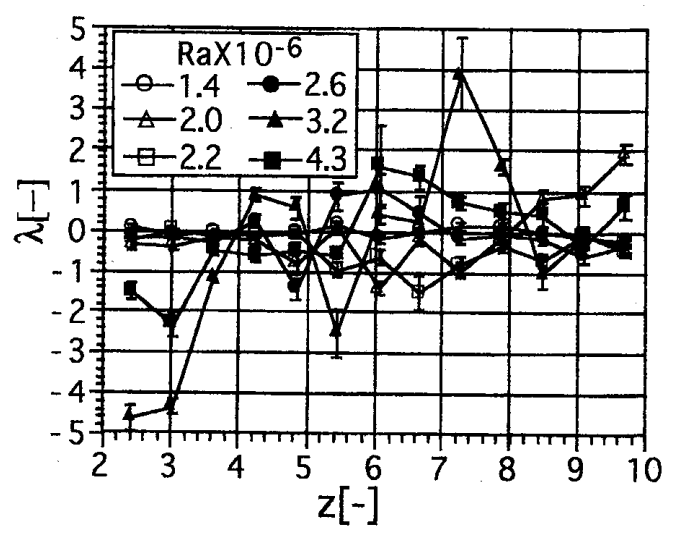

Fig. 8 The largest Lyapunov exponents for various Ra

以上の方法により $\lambda$ とその誤差範囲を計算した結果 を図 8 に誤差線付きで示している. $\lambda>0$ でかつ誤差範 囲内部に $\lambda=0$ の点が存在しないケースを有意なカオス 性ありと判断するならぱ，有意な力オス性は 2 次流れ セルが存在する 5 つのケースのうち, $\operatorname{Ra} \times 10^{-6}=2.6,3.2$, 4.3 の 3 つのースで検出され，表 1 と図 8 を比較す るとその範囲は例外を除き 2 次流れセルが存在する領 域の最上部に位置しており，この領域は表 2 によると 特徴周波数が検出される領域にほぼ対応している。 の結果はカオス性が検出される領域が 2 次流れセルの 存在する領域に含まれるという点では鉛直平行平板間 の自然対流場の結果と一致する. また既報 ${ }^{10)} の$ 鈆直平 
行平板間の結果と同じく, $\lambda$ 滈さ方向にいったん最 大値をとったあと減少している.

またこの結果を図 5 の温度振幅の定性的傾向と比較 すると 2 次流れセルの存在領域の上部では温度振幅が 十分大きく，多くのケースで高さ方向に增大している にも関わらずカオス性は小さくなっているということ になり，これは既報 ${ }^{109} の$ 鈶直平行平板間の自然対流場 においてカオス性の大きい領域と温度振幅の大きい領 域は対応が見られたという結果と異なっている。これ は主として一定発熱条件に基づく相違であると考兄ら れるが, カオス性は本来時間変動特性の一種であって， その変動の振幅（変動エネルギー）とは無関係である ということを示す物理現象の例として注目される.

図 8 で $R a=1.4 \times 10^{6}, 2.0 \times 10^{6}$ のケースのうちいく つかの測定点でのデータについて有意なカオス性が検 出されている(特に $\mathrm{Ra}=2.0 \times 10^{6}$ で $\mathrm{z}=8.5,9.1,9.7$ のケ 一ス)が，これらのケースでは元々温度振幅が極めて小 さく，また対応する位置に 2 次流れセルは存在しない ため物理的にカオス性が検出させる理由は考えられな い，完全にランダムな時系列デー夕は無限自由度を有 しており，有限の埋め込み次元では解析が不可能であ るが，これらのケースで埋め込み次元に対して stationarity が確認できなかった事実を考慮すると，上 述の結果はノイズの影響によるものと思われる。

また $\mathrm{Ra}=4.13 \times 10^{6}$ では 2 次流れセルの上部でも有意 なカオス性が検出されているが，これ性 4.1,4.2 節で 指摘した流れの構造変化によるものと考劣られ，4.3 節で示した $\tau$ が 2 次流れセルの上部で比較的小さい值 を保っているという事実に対応している。

\section{5. 結言}

本論文では内円筒にヒ一夕を埋め込んで加熱し，外 円筒を温度一定で泠却することにより，グリセリン水 溶液を注入した円筒間内部に生じる熱対流場の周波数 特性，時間変動スケール並びにカオス性について実験 的な検討を行い，既報の鈶直平行平板間の結果と比較 考察を行った. 主たる結果は以下の通りである.

(1)レイリー数を大きくするに連れて2 次流れセルが

発生する領域は広くなるが，その上限はほぼ一定で 下限が下方へ移動し，側壁温度一定の鉛直平行平板 間でみられた中心対称性は見られない.

(2)場に特有な温度変動の周波数成分が検出される領 域は 2 次流れセルが存在する領域の最上部に偏る. この点についても 2 次流れセルの存在領域と特徽 周波数の検出される領域がほぼ一致する鈶直平行
平板間の結果と異なる。

(3) 2 次流れセルが観察されるレイリー数のケースで は 2 次流れセルが存在する領域内部で ACFが 1/eに なるスケールてが高さ方向にいったん減少したあと 増加する傾向があり，その値は 2 次流れセルの存在 領域内部で全体的に小さくなるがこれは鈆直平行 平板間の自然対流場の結果と対応する.

(4)有意な温度変動のカオス性が検出される領域は 2 次流れセルの存在する領域の最上部に位置しこれれ は特徴周波数の検出される領域にほぼ一致する.こ の結果はカオス性が検出される領域が 2 次流れセ ルの存在する領域に含まれるという点では鉛直平 行平板間の自然対流場の結果と一致する。

\section{文献}

1)Prasad, V. and Kulacki, F. A., Free Convective Heat Transfer in a Liquid-Filled Vertical Annulus, ASME J. Heat Transfer, 107(1985), 596-602

2)Keyhani, M., Kulacki, F. A. and Christensen, R. N., Free Convection in a Vertical Annulus with Constant Heat Flux on the Inner Wall, ASME J. Heat Transfer, 105(1983), 454-459

3)Fujii, T. et al, Experiments on Natural-Convection Heat Transfer from the Outer Surface of a Vertical Cylinder to Liquids, Int. J. Heat Mass Transfer, 13(1970), 753-787

4)Khan, J. A. and Kumar, R, Natural Convection in Vertical Annuli: A Numerical Study for Constant Heat Fux on the Inner Wall, ASME J. Heat Transfer, 111(1989), 909-915

5)Ho, C. J. and Lin, Y. H., Natural Convection of Cold Water in a Vertical Annulus With Constant Heat Flux on the Inner Wall, ASME J. Heat Transfer, 112(1990), 117-123

6)Ho, C. J. and Tu, F. J., Transition to Oscillatory Natural Convection of Cold Water in a Vertical Annulus, Int. J. Heat Mass Transfer, 41(1998), 1559-1572

7)石田秀士・本本日出夫,容器内自然対流場における平均熱伀 達特性に対する加振の影響，譏論 B, 65(1999), 2413-2419

8)石田秀士・吉网棡・山下隆之・木本日出夫,水平加熱体上方 の自然対流埸の安定性とカオス性, 66(2000), 1845-1852

9)石田秀士・木本日出夫,容器内の振動熱対流場に㧍ける平均 熱伝達率の時系列データから再構築されるアトラクタの幾 何学構造,機論 B,65(1999),2420-2425

10)石田秀士・久䣓一樹・本本日出夫, 鈆直平行平板間の自然 対流場の淮定常性とカオス性，機論 B,65(1999), 761-767

11)Segur, J. B., Physical Properties of Glycerol and its Solutions, Glycerol(ed. Miner, C. S. and Dalton, N. N.), 238-334, Reinhold

12)Wakitani, S., Experiments on Convective Instability of Large Prandtl Number Fluids in a Vertical Slot, ASME J. Heat Transfer, 116(1994), 120-126

13)Lawkins, W. F., Daw, C. S., Downing, D. J. and Clapp N. E., Jr., Role of low-pass filtering in the process of attractor reconstruction from experimental chaotic time series, Phy. Rev. E, 47(1993), 2520-2535

14)Wolf, A., Swift, J. B., Swinney, H. L. and Vastano, J. A., Determining Lyapunov Exponents From a Time Series, Physica 16D, (1985), 285-317 